\title{
MENINGKATKAN HASIL BELAJAR LARI SPRINT MELALUI PERMAINAN HITAM HIJAU PADA SISWA
}

\author{
Andreas Juhara \\ SD Negeri Padamenak Kecamatan Jalaksana \\ Email: mas'ud12@gmail.com
}

\begin{abstract}
Abstrak
Pembelajaran lari sprint siswa kelas $V$ SD Negeri Padamenak banyak mengalami permasalahan yang timbul dalam pembelajaran dengan hasil pembelajaran siswa yang kurang dari nilai rata-rata dibawah nilai KKM 75 yang telah ditentukan guru. Penelitian ini bertujuan untuk meningkatkan hasil belajar lari sprint melalui permainan hitam hijau pada siswa kelas $V$ SD Negeri Padamenak Kecamatan Jalaksana Kabupaten Kuningan Tahun Pelajaran 2014/2015. Penelitian ini menggunakan metode penelitian tindakan kelas (Class Action Research), tindakan dalam penelitian ini dibagi dalam dua siklus, dalam tiap siklus menunjukan perkembangan proses pembelajaran jasmani pada materi lari sprint. Subjek penelitian ini adalah siswa kelas V SD Negeri Padamenak pada semester II tahun pelajaran 2014/2015 yang berjumlah 50 siswa terdiri atas 22 siswa putra dan 28 siswa putri. Instrumen yang digunakan untuk pengambilan data pada penelitian ini adalah lembar pengamatan, dan tes unjuk kerja siswa. Analisis data yang digunakan dalam penelitian ini adalah analisis deskriptif. Data penelitian ini berupa hasil belajar siswa yang meliputi ranah afektif, kognitif, dan psikomotor. Data penelitian menunjukan bahwa pelaksanaan pembelajaran lari sprint melalui penerapan permainan hitam hijau dapat meningkatkan hasil belajar lari sprint dari kondisi awal persentase siswa yang nilainya mencapai KKM 75 sebesar $40 \%$ atau 20 anak dari jumlah keseluruhan siswa, pada tindakan siklus pertama persentase siswa yang nilainya mencapai KKM mencapai 70\% atau sebanyak 35 siswa kemudian pada siklus kedua persentase ketuntasan belajar mencapai $86 \%$ atau sebanyak 43 siswa. Hasil penelitian ini dapat disimpulkan bahwa melalui penerapan permainan hitam hijau pada materi pembelajaran lari sprint dapat meningkatkan hasil belajar siswa pada siswa kelas V SD Negeri Padamenak Kecamatan Jalaksana Kabupaten Kuningan. Penulis memberi saran bagi guru hendaknya terus berusaha untuk meningkatkan kemampuannya dalam mengembangkan materi, menyampaikan materi, sehingga kualitas pembelajaran yang dilakukan dapat meningkat sehingga tujuan pembelajaran bisa tercapai.
\end{abstract}

Kata Kunci: Lari, Sprint, Permainan, Hitam, Hijau

Abstract

Sprint running learning in class V SD Negeri Padamenak experienced many problems that arise in learning with student learning outcomes that are less than the average value below the KKM value 75 that has been determined by the teacher. This study aims to improve the learning outcomes of sprint running through black and green games in fifth grade students of 
Padamenak State Elementary School, Jalaksana District, Kuningan District 2014/2015 Academic Year. This study uses a class action research method, the action in this study is divided into two cycles, in each cycle shows the development of the physical learning process on sprint running material. The subjects of this study were fifth grade students of Padamenak Elementary School in the second semester of the 2014/2015 academic year, totaling 50 students consisting of 22 male students and 28 female students. The instruments used for data collection in this study are observation sheets, and student performance tests. The data analysis used in this study is descriptive analysis. The research data is in the form of student learning outcomes which include affective, cognitive, and psychomotor domains. The research data shows that the implementation of sprint running learning through the application of black and green games can improve sprint learning outcomes from the initial conditions the percentage of students reaching KKM 75 by $40 \%$ or 20 children from the total number of students, in the first cycle action the percentage of students reaches KKM reaching $70 \%$ or as many as 35 students then in the second cycle the percentage of learning completeness reached $86 \%$ or as many as 43 students. The results of this study can be concluded that through the application of black and green games on sprint running learning material can improve student learning outcomes in fifth grade students of Padamenak Elementary School, Jalaksana District, Kuningan Regency. The author advises teachers that they should continue to strive to improve their ability to develop material, deliver material, so that the quality of learning can be increased so that the learning objectives can be achieved.

Keywords: Running, Sprint, Game, Black, Green

\section{PENDAHULUAN}

Pendidikan jasmani pada dasarnya merupakan bagian integral dari sistem pendidikan secara keseluruhan. Oleh karena itu, pelaksanaan pendidikan jasmani harus di arahkan pada pencapaian tujuan tersebut. Tujuan pendidikan jasmani bukan hanya mengembangkan ranah jasmani, tetapi juga mengembangkan aspek kesehatan, ketrampilan berfikir kritis, stabilitas emosional, ketrampilan sosial dan tindakan moral melalui kegiatan aktifitas jasmani dan olahraga. Pendidikan jasmani olahraga dan kesehatan merupakan media untuk mendorong pertumbuhan fisik, perkembangan psikis, ketrampilan motorik, pengetahuan dan penalaran, penghayatan nilai-nilai (sikap, mental, emosional, sportifitas, spiritual, sosial) serta pembiasaan pola hidup sehat yang bermuara untuk merangsang pertumbuhan dan perkembangan kualitas fisik dan psikis yang seimbang.

Sesuai dengan karakteristik siswa $\mathrm{SD}$, usia 6-13 tahun kebanyakan dari mereka cenderung masih suka bermain. Untuk itu guru harus mampu mengembangkan pembelajaran yang efektif, disamping harus memahami dan memperhatikan karakteristik dan kebutuhan siswa. Pada usia tersebut seluruh aspek perkembangan manusia baik kognitif, psikomotor dan afektif mengalami perubahan. Agar standar kompetensi pembelajaran pendidikan jasmani dapat terlaksana sesuai dengan pedoman, maksud dan tujuan sebagaimana yang ada di dalam kurikulum maka guru pendidikan jasmani 
harus mampu membuat pembelajaran yang efektif dan tidak membosankan. Untuk itu perlu adanya pendekatan, variasi maupun modifikasi dalam pembelajaran. Atletik adalah induk dari segala cabang olahraga. Nomor-nomor atletik dapat dibagi : lari, lompat dan lempar. Kemampuan lari, lompat dan lempar sudah dimiliki sejak dahulu, dengan tujuan untuk mempertahankan diri dalam berburu. Dengan alasan-alasan itulah, seharusnya atletik dapat digemari oleh anak didik.

Pembelajaran lari sprint siswa kelas V Sekolah Dasar Negeri Padamenak Kecamatan Jalaksana Kabupaten Kuningan, banyak mengalami permasalahan yang timbul dalam pembelajaran dengan hasil pembelajaran siswa yang kurang dari nilai rata-rata dibawah nilai KKM 75 yang telah ditentukan guru. Beberapa faktor yang menyebabkan tidak tercapainya kriteria ketuntasan minimal (KKM) adalah pembelajaran yang monoton, kurangnya pengembangan pembelajaran, tingkat pemahaman siswa yang rendah, kurangnya minat siswa terhadap materi lari sprint, banyak siswa enggan melaksanakan kegiatan yang diberikan oleh guru karena kebanyakan siswa mempunyai pandangan bahwa lari adalah kegiatan melelahkan sehingga mengakibatkan siswa tidak tertarik dengan kegiatan lari.

Hambatan-hambatan diatas menjadi permasalahan guru dalam melaksanakan pembelajaran terutama pada materi lari sprint. Faktor terpenting dalam pembelajaran lari untuk SD kelas atas adalah metode pembelajaran mengandung unsur teknik dasar lari dan menarik bagi siswa sehingga siswa tidak mengalami kejenuhan dalam mengikuti pembelajaran. Sehingga guru harus menerapkan pendekatan pembelajaran yang dikemas melalui permainan hitam hijau agar siswa merasa senang dan antusias dalam mengikuti kegiatam belajar mengajar pembelajaran lari sprint, dengan harapan pembelajaran lari sprint dapat disenangi oleh siswa sehingga tercapai tujuan pembelajaran yang diharapkan.

Salah satu cara menumbuhkan atau meningkatkan keaktifan siswa dalam mengikuti pembelajaran pendidikan jasmani adalah dengan metode bermain, dalam penelitian tindakan kelas ini peneliti bermaksud ingin menerapkan permainan hitam hijau dalam pelaksanaan pembelajaran lari sprint dengan harapan dapat meningkatkan hasil belajar siswa. Setelah peneliti mengamati hal-hal tersebut, peneliti mencoba menerapkan pembelajaran dengan metode pendekatan bermain, peneliti berupaya memasukan unsur permainan kedalam materi lari sprint dengan tujuan agar siswa merasa senang, tidak merasa jenuh dalam kegiatan pembelajaran serta menciptakan suasana kegembiraan dengan harapan materi lari sprint dapat disenangi oleh siswa sehingga tercapai tujuan pembelajaran. 


\section{METODE}

Metode yang digunakan dalam penelitian ini adalah metode kualitatif dengan teknik penelitian tindakan kelas (classroom action research). PTK dalam Penjas adalah suatu bentuk kajian yang bersifat reflektif dan dilakukan untuk meningkatkan kemampuan rasional dari tindakan-tindakan guru dalam memperdalam tugas, memperdalam pemahaman terhadap tindakan-tindakan yang dilakukannya, serta memperbaiki kondisi dimana praktek pembelajaran penjas tersebut dilakukan, dimulai dari adanya perencanaan, pelaksanaan, observasi, dan refleksi untuk setiap siklusnya. (Agus, 2010:32). Subjek penelitian adalah siswa kelas V SD Negeri Padamenak semester II tahun Pelajaran 2014/2015 yang berjumlah 50 siswa, terdiri dari 22 siswa laki-laki dan 28 siswa perempuan. Teknik pengumpulan data dalam Penelitian Tindakan Kelas (PTK) ini terdiri dari tes dan observasi. Instrumen yang digunakan dalam penelitian menggunakan tes lari cepat 30 meter untuk siswa SD, (Nurhasan, 2007:101), dan lembar observasi untuk mengukur aspek kognitif siswa. Analisis data yang digunakan yaitu data kuantitatif dan data kualitatif. Data kuantitatif berupa hasil belajar lari sprint dianalisis dengan menggunakan teknik analisis deskriptif dengan menentukan presentasi ketuntasan belajar dan mean (rata-rata) kelas. Sedangkan data kualitatif dipaparkan dalam kalimat yang dipisahkan menurut kategori untuk memperoleh kesimpulan.

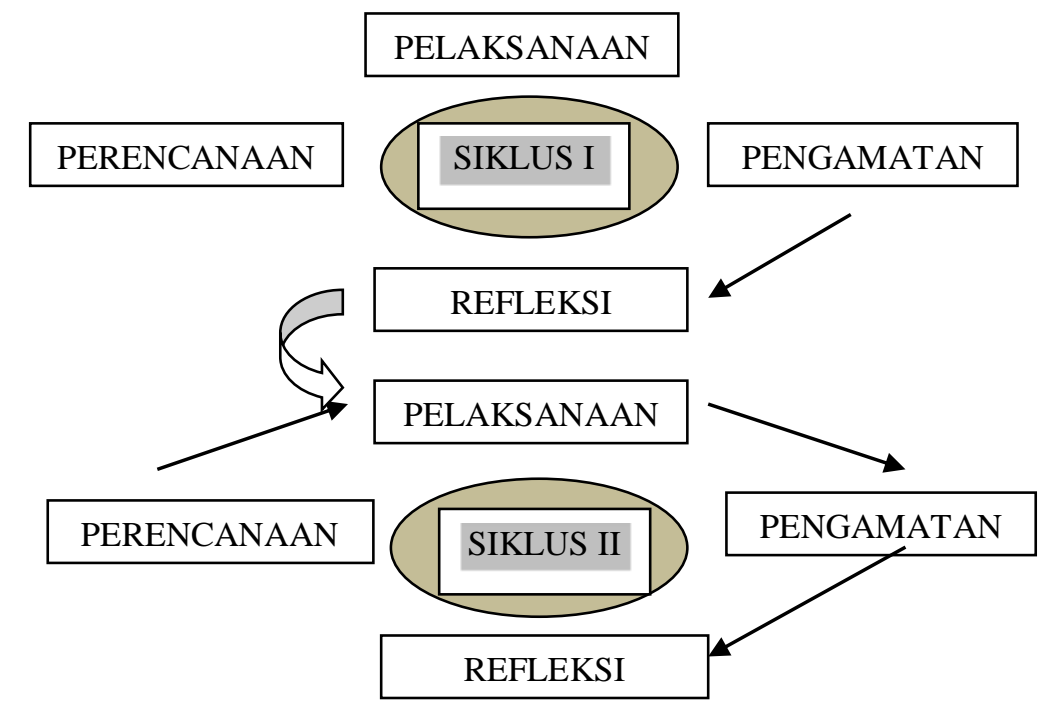

Gambar 1. Alur Siklus Penelitian Tindakan Kelas Sumber : Arikunto, 2008:16 
HASIL PENELITIAN

\section{Perbandingan Peningkatan Nilai Hasil}

Belajar Lari sprint dari Kondisi Awal ke

Siklus I

Perbandingan peningkatan nilai ketuntasan belajar lari sprint siswa kelas $\mathrm{V}$ SD Negeri Padamenak dari kondisi awal ke siklus I disajikan dalam bentuk tabel berikut:

Lebih jelasnya berikut ini disajikan diagram peningkatan nilai rata-rata hasil belajar lari sprint siswa kelas V SD Negeri Padamenak dari kondisi awal ke siklus 1 sebagai berikut:

\begin{tabular}{|c|c|c|}
\hline $\begin{array}{c}\text { Nilai Terendah Lari } \\
\text { sprint Kondisi Awal Pra } \\
\text { Siklus }\end{array}$ & $\begin{array}{c}\text { Nilai Terendah pada } \\
\text { siklus I }\end{array}$ & $\begin{array}{c}\text { Peningkatan Kualitas } \\
\text { Belajar Lari sprint Siklus } \\
\text { I }\end{array}$ \\
\hline 68 & 69 & 1,00 \\
\hline $\begin{array}{c}\text { Nilai Tertinggi Lari } \\
\text { sprint Kondisi Awal Pra } \\
\text { siklus }\end{array}$ & $\begin{array}{c}\text { Nilai Tertinggi pada } \\
\text { siklus I }\end{array}$ & $\begin{array}{c}\text { Peningkatan Kualitas } \\
\text { Belajar Lari sprint Siklus } \\
\text { I }\end{array}$ \\
\hline 81 & 82 & 1,00 \\
\hline
\end{tabular}

Tabel 1. Perbandingan Peningkatan Kualitas Belajar Lari sprint Siswa Kelas V SD Negeri Padamenak dari kondisi awal ke siklus I.

Aktivitas pembelajaran yang dilaksanakan oleh guru pada pertemuan I mulai terlihat cukup baik, hal tersebut terlihat dengan perolehan nilai dari aspek penilaian yang hanya mencapai 3,57 dari skala nilai $1-5$.

Setelah melaksanakan refleksi dengan rekan sejawat dan membahas kekurangan dalam pembelajaran maka pertemuan ke II dimana nilai rata- ratanya menjadi meningkat yaitu 4,71 pada skala nilai $1-5$.
Berdasarkan dari hasil tes pembelajaran diatas kemudian dimasukan dalam grafik Teknik siswa sebagai berikut. 


\begin{tabular}{|c|c|c|}
\hline $\begin{array}{c}\text { Nilai Terendah Lari sprint } \\
\text { Kondisi Awal Pra Siklus }\end{array}$ & Nilai Terendah pada siklus I & $\begin{array}{c}\text { Peningkatan Kualitas } \\
\text { Belajar Lari sprint Siklus I }\end{array}$ \\
\hline 68 & 69 & 1,00 \\
\hline $\begin{array}{c}\text { Nilai Tertinggi Lari sprint } \\
\text { Kondisi Awal Pra siklus }\end{array}$ & Nilai Tertinggi pada siklus I & $\begin{array}{c}\text { Peningkatan Kualitas } \\
\text { Belajar Lari sprint Siklus I }\end{array}$ \\
\hline 81 & 82 & 1,00 \\
\hline
\end{tabular}

Tabel 2. Perbandingan Peningkatan Kualitas Belajar Lari sprint Siswa Kelas V SD Negeri Padamenak dari kondisi awal ke siklus I

Dari diagram di atas jelas terlihat perbandingan jumlah siswa yang memperoleh nilai ketuntasan diatas KKM meningkat dari pra siklus sejumlah 35 siswa sehingga menunjukan bahwa nilai hasil belajar lari sprint siswa kelas V SD Negeri Padamenak mengalami peningkatan yang cukup baik. Hal ini memperlihatkan bahwa nilai hasil belajar lari sprint dari kondisi awal ke siklus I mengalami peningkatan rata-rata sebesar 3,00.

\section{Perbandingan Peningkatan Nilai Hasil} Belajar Lari sprint dari Siklus I ke Siklus II

Perbandingan peningkatan nilai hasil belajar lari sprint siswa kelas V SD Negeri Padamenak dari siklus I ke siklus II disajikan dalam bentuk tabel berikut:

\begin{tabular}{|c|c|c|}
\hline $\begin{array}{c}\text { Nilai Terendah Lari sprint } \\
\text { Kondisi Awal Pra Siklus }\end{array}$ & $\begin{array}{c}\text { Nilai Terendah pada siklus } \\
\text { II }\end{array}$ & $\begin{array}{c}\text { Peningkatan Kualitas } \\
\text { Belajar Lari sprint Siklus II }\end{array}$ \\
\hline 69 & 70 & 1,00 \\
\hline $\begin{array}{c}\text { Nilai Tertinggi Lari sprint } \\
\text { Kondisi Awal Pra siklus }\end{array}$ & $\begin{array}{c}\text { Nilai Tertinggi pada siklus } \\
\text { II }\end{array}$ & $\begin{array}{c}\text { Peningkatan Kualitas } \\
\text { Belajar Lari sprint Siklus II }\end{array}$ \\
\hline 82 & & 3,00 \\
\hline
\end{tabular}

Tabel 3. Perbandingan Peningkatan Kualitas Hasil Belajar Lari sprint Siswa Kelas V SD Negeri Padamenak dari siklus I ke siklus II

Berdasarkan hasil penelitian yang telah dilakukan pada siklus I jumlah siswa yang mendapatkan nilai diatas KKM berangsur-angsur naik, sehingga pada siklus II jumlah tersebut sudah melebihi target. Kemajuan ini terjadi karena siswa merasa 
senang dengan penerapan permainan hijauhitam, lebih bersemangat dan aktif mengikuti proses pembelajaran serta peneliti selalu memberikan dorongan dan motivasi belajar. Hal ini sejalan dengan adanya perubahan perilaku peserta didik yang menunjukan keaktifan dalam mengikuti proses pembelajaran dengan baik (Moh. Surya, 1997). Penerapan pembelajaran melalui permainan yang bersifat tantangan berbentuk perlombaan akan berdampak dalam menumbuhkan minat, meningkatkan kepercayaan diri siswa, meningkatkan kemampuan motorik anak (Sugiyanto dan Sujarwo, 1992:127128). Sehingga dapat disimpulkan melalui penerapan permainan hitam hijau pembelajaran materi lari sprint dapat meningkatkan hasil belajar siswa, meningkatkan kualitas pembelajaran, meningkatkan ketuntasan hasil belajar serta menciptakan pembelajaran yang aktif, inovatif, kreatif, efektif dan menyenangkan (PAIKEM) sehingga tujuan pembelajaran bisa tercapai.

Kondisi awal hasil belajar lari sprint pada siswa kelas V SD Negeri Padamenak Kecamatan Jalaksana Kabupaten Kuningan Tahun Ajaran 2014/2015 diketahui melalui tes awal lari sprint. Pelaksanaan pembelajaran dengan pendekatan bermain dilakukan dengan cara memilih jenis permainan yang gerakannya memuat unsur gerakan teknik dasar lari cepat berupa permainan berlari memindahkan benda dan permainan hitam hijau. Untuk memenuhi unsur gerakan teknik dasar lari sprint dalam penelitian tindakan kelas ini guru memilih permainan sederhana yang berkembang dikalangan masyarakat terutama yang populer dalam kalangan anak-anak, yaitu permainan hitam hijau. Penerapan permainan hitam hijau dimaksudkan untuk membiasakan siswa dalam melatih gerak dasar lari sprint berupa teknik dasar lari.

Untuk melatih kecepatan reaksi dalam permainan ini bisa dimodifikasi terlebih dahulu dengan permainan memindahkan bola atau bendera. Data kondisi awal pra siklus persentase hasil belajar lari sprint siswa kelas V SD Negeri Padamenak sangat rendah menunjukan $40 \%$ atau siswa yang mencapai ketuntasan belajar hanya sejumlah 20 siswa. Sedangkan nilai rata-rata hasil belajar lari sprint sebesar 73,00. Melalui deskripsi data awal yang telah diperoleh tersebut menunjukan kualitas pembelajarn masih rendah, ketidakberhasilan guru dalam menyajikan materi pembelajaran. Maka disusun rencana pelaksananaan penelitian tindakan kelas untuk mengoptimalkan kualitas pembelajaran materi lari sprint pada siswa kelas V Sekolah Dasar Negeri Padamenak melalui permainan hijau hitam. Rencana pelaksanaan tindakan akan dilaksanakan dalam 2 siklus, dan masingmasing siklus terdiri dari 4 tahapan yaitu: (1) perencanaan, (2) pelaksanaan, (3) observasi, (4) analisis dan refleksi. 
Pelaksanaan tindakan dalam siklus I yang dilakukan peneliti dan dibantu kolaborator adalah mengambil data penelitian berupa nilai ketuntasan hasil belajar. Data hasil ketuntasan belajar siswa pada materi lari sprint melalui penerapan permainan hijau hitam dianalisis melalui pencapaian indikator yang telah ditentukan. Adapun deskripsi data peningkatan kemampuan lari sprint pada siklus I ketuntasan belajar mencapai $70 \%$. Data tersebut menunjukan adanya kemajuan hasil belajar materi sprint pada siswa kelas V SD Negeri Padamenak Kecamatan Jalaksana Kabupaten Kuningan Tahun Ajaran 2014/2015. Kemajuan hasil belajar ini karena adanya 15 siswa yang memperoleh nilai diatas KKM dari kondisi awal pra siklus ke siklus I. Sehingga jumlah keseluruhan ketuntasan belajar pada siklus I sejumlah 35 siswa. Kualitas gerak serta jawaban siswa cukup memadai karena dari 50 siswa yang bisa menjawab dengan benar sejumlah 35 sedangkan 15 siswa lainnya jawabannya masih kurang. Kemampuan menjawab soal dapat dikatakan bagus karena jawaban tersebut dikomentari dengan kata-kata logis, singkat, kalimat bagus dan benar. Sedangkan nilai rata-rata hasil belajar meningkat sejumlah 76,00.

Dalam pelaksanaan siklus I terdapat kelebihan yang dapat digunakan sebagai tolok ukur keberhasilan sehingga dapat dijadikan bahan pada saat pelaksanaan siklus II, adapun kelebihannya antara lain:
1) adanya kemajuan siswa telah mampu melakukan lari sprint mulai dari awalan start, saat melakukan awalan lari dan sikap badan saat melewati garis finish 2). penerapan permainan hijau hitam pada materi lari sprint membuat siswa lebih tertarik, lebih bersemangat, senang, dan sehingga aktif dalam mengikuti pembelajaran. Namun dalam pelaksanaan tindakan siklus I juga masih terdapat kelemahan atau kekurangan, adapun kelemahan atau kekurangan tersebut antara lain masih ada siswa yang kurang serius dalam mengikuti pembelajaran, ada siswa bercanda, sehingga siswa lain terganggu dan mengakibatkan pembelajaran kurang maksimal. Kelemahan tersebut dijadikan bahan pengembangan penerapan pembelajaran pada siklus II dengan cara peneliti lebih aktif memperhatikan siswa yang kurang serius dalam mengikuti proses pembelajaran serta memberikan dorongan agar siswa tersebut lebih aktif, untuk mendorong siswa agar lebih aktif dalam melakukan permainan, sebaiknya peneliti memberikan applouse / pujian. Hasil observasi atau pengamatan serta hasil refleksi selama pelaksanaan siklus I dapat diidentifikasikan belum berhasil atau tuntas sesuai dengan persentase target pencapaian sehingga penelitian dilanjutkan ke siklus II.

Pelaksanaan siklus II peneliti melakukan penelitian kembali dengan berpedoman dari hasil siklus I serta mengambil data yang diperlukan sebagai 
bahan evaluasi. Data peningkatan nilai hasil belajar lari sprint pada siswa kelas V SD Negeri Padamenak dari siklus I ke siklus II menunjukan peningkatan rata-rata sebesar 2,00. Sedangkan nilai rata-rata hasil belajar lari sprint mengalami peningkatan sebesar 78,00. Hal ini menunjukan bahwa, penerapan permainan hijau-hitam untuk meningkatkan kemampuan lari sprint siswa pada siklus II telah berhasil. Kemajuan hasil belajar ini ditandai dengan adanya peningkatan ketuntasan belajar 8 siswa yang memperoleh nilai diatas KKM dari kondisi siklus I ke siklus II. Sehingga jumlah keseluruhan ketuntasan belajar sampai akhir siklus II sejumlah 43 siswa (86\%). Kualitas gerak serta jawaban siswa cukup baik karena dari 50 siswa yang bisa menjawab dengan benar sejumlah 43 siswa sedangkan 7 siswa lainnya jawabannya kurang sempurna. Kemampuan menjawab soal dapat dikatakan semakin bagus karena jawaban tersebut dikomentari dengan katakata logis, singkat, kalimat bagus dan benar.

Selama pelaksanaan siklus II terdapat kelebihan yang dapat digunakan sebagai tolok ukur keberhasilan, adapun kelebihannya antara lain: 1) sebagian besar siswa telah mampu melakukan lari sprint mulai dari awalan start, saat melakukan awalan lari dan sikap badan saat melewati garis finish 2). Melalui pembelajaran dengan penerapan pembelajaran hijau hitam pada materi lari sprint siswa lebih tertarik, lebih antusias, senang, dan aktif dalam mengikuti pembelajaran. 3) kualitas jawaban yang diberikan lebih baik dengan menggunakan tata bahasa yang bagus, singkat dan benar. Hasil observasi atau pengamatan serta refleksi selama pelaksanaan siklus II dapat diidentifikasikan telah berhasil atau tuntas sesuai dengan persentase target pencapaian yaitu $80 \%$ sehingga penerapan permainan hitam hijau pada materi lari sprint telah berhasil sesuai dengan tujuan peneliti.

\section{SIMPULAN}

Melalui penerapan permainan hitam hijau dapat meningkatkan hasil belajar lari sprint pada siswa kelas V SD Negeri Padamenak Kecamatan Jalaksana Kabupaten Kuningan Tahun Pelajaran 2014/2015 ditandai dengan meningkatnya ketuntasan nilai hasil belajar. Hal ini sejalan dengan hasil data temuan yang diperoleh peneliti pada kondisi awal pra siklus ke siklus I sampai akhir siklus II. Persentase nilai ketuntasan hasil belajar siswa kelas $\mathrm{V}$ SD Negeri Padameank pada kondisi awal pra siklus sebesar (40\%) atau sejumlah 20 siswa yang mencapai ketuntasan belajar dari 50 siswa keseluruhan, kemudian pada siklus I terjadi peningkatan sebesar (70\%) atau sejumlah 35 siswa dan pada akhir siklus II meningkat sebesar (86\%) atau sejumlah 43 siswa yang mencapai ketuntasan belajar, sehingga peningkatan dari kondisi awal pra siklus hingga akhir siklus II sebesar (46\%). Hal ini sejalan 
dengan adanya perubahan perilaku peserta didik yang menunjukan keaktifan dalam mengikuti proses pembelajaran dengan baik (Moh. Surya, 1997). Penerapan pembelajaran melalui permainan yang bersifat tantangan berbentuk perlombaan akan berdampak dalam menumbuhkan minat, meningkatkan kepercayaan diri siswa, meningkatkan kemampuan motorik anak (Sugiyanto dan Sujarwo, 1992:127128).

Penelitian ini memberikan suatu gambaran yang jelas bahwa keberhasilan proses pembelajaran tergantung dari pihak guru maupun siswa serta metode pembelajaran yang digunakan. Kemampuan guru dalam mengembangkan materi, menyampaikan materi, mengelola kelas, metode yang digunakan dalam proses pembelajaran, serta teknik yang digunakan guru sebagai sarana untuk menyampaikan materi perlu diperhatikan. Faktor dari siswa yaitu, minat dan motivasi dalam mengikuti proses pembelajaran, ketersediaan alat/media pembelajaran yang menarik dapat membantu siswa dalam mengikuti pembelajaran, sehingga akan diperoleh hasil belajar yang efektif, efisien dan optimal.6

\section{DAFTAR PUSTAKA}

Abdul Kadir Ateng,(1992), Azas dan Landasan Pendidikan Jasmani. Jakarta Depdikbud Dirjen Dikti
Abin Syamsudin M, 2002. Pendekatan Dan

Metode Pembelajaran.

Agus Mahendra, 2008. Permainan Anak dan Aktivitas Ritmik. Jakarta: Universitas Terbuka

Anni, C.T,(2004). Psikologi Belajar. Semarang: UNNES Press

Depdiknas. 2003. Undang - Undang RI Tahun 2003 tentang Sistem Pendidikan Nasional. Jakarta. Depdiknas.

Moh. Surya, 1997. Ciri-ciri perubahan perilaku belajar dari beberapa ahli pendidika.

Nadisah, (1992).Pengembangan kurikulum pendidikan jasmani dan kesehatan. Jakarta: Depdikbud Dirjen Dikti

Rumini, 2003. Model Pembelajaran Atletik, Sekolah Dasar dan Madrasah Ibtidaiyah. Depdiknas.

Sudjana, (1990). Strategi Pembelajaran.

Soegijanto, soedjarwo, (1992). Permainan Kecil.Jakarta: Depdikbud Dirjen Dikti Suryo,(1992). Psikologi Belajar. Jakarta: Universitas Terbuka Waluyo, (2011). Teknologi Pendidikan dalam Penjas. Universitas Sebelas Maret Surakarta

Yosaphat Sumardi, 2000. Dasar - Dasar Atletik. Universitas Terbuka. Depdikbub.

Yoyo, B. Yusuf, U., Suherman, A. (2000), Atletik. Depdikbud.

Dirjendikdasmen. 